\title{
Controlled Release of Essential Oil from a Rubberwood Box Using Activated Carbon to Extend the Shelf Life of Strawberries and its Possible Mode of Action
}

\begin{abstract}
Saifon Phothisuwan, ${ }^{\text {a,c }}$ Nirundorn Matan, ${ }^{\mathrm{b}}$ and Narumol Matan ${ }^{\mathrm{a}, \mathrm{c}, *}$
The controlled release of bergamot oil was evaluated from rubberwood boxes containing activated carbon and bergamot oil. Rubberwood boxes impregnated with different concentrations of bergamot oil $(50,100$, and $300 \mu \mathrm{g} \mathrm{g}^{-1}$ ) with and without activated carbon were prepared. The treated rubberwood boxes were utilized to store strawberries at $6^{\circ} \mathrm{C}$ for $21 \mathrm{~d}$, while boxes with only activated carbon were used as a control. The inhibitory effects relative to Botrytis cinerea growth and quality of the strawberries after storage in rubberwood box were investigated. The microstructure of the rubberwood was evaluated via scanning electron microscopy. Gas chromatography mass spectrometry was used to quantify the volatile compounds. The rubberwood boxes with activated carbon and $100 \mu \mathrm{g} \mathrm{g}^{-1}$ of bergamot oil were found to inhibit Botrytis cinerea growth on strawberries and extend their shelf life for at least $21 \mathrm{~d}$. Compared to rubberwood boxes without activated carbon, activated carbon was able to retard the release of bergamot oil into the system, yielding increased strawberry quality. Releasing less bioactive components from bergamot oil could decrease undesirable effects on strawberries, e.g., tissue, weight loss, flavour, and colour changes.
\end{abstract}

Keywords: Control release; Activated carbon; Rubberwood box; Strawberry; Bergamot oil

Contact information: a: Food Industry, School of Agricultural Technology and Food Industry, Walailak University, Thasala, Nakhon Si Thammarat 80160 Thailand; b: Center of Excellence in Wood Science and Engineering, School of Engineering and Technology, Walailak University, Thasala, Nakhon Si Thammarat 80160 Thailand; c: Research Center of Excellence in Innovation of Essential Oil, Walailak University, Nakhon Si Thammarat 80160 Thailand; *Corresponding authors: phothisuwan.me@gmail.com; nnarumol@wu.ac.th; nnarumol@yahoo.com

\section{INTRODUCTION}

Due to increasing volumes of fruits that are sold, wooden containers are one of the fast-growing segments for agricultural transportation, both in domestic and international markets. Crates or rubberwood boxes tend to comprise a majority of these items, because they are light, inexpensive, and reusable. Commercial rubberwood boxes for food are treated with preservative solutions, natural extracts, volatile compounds, and essential oils to improve the flavour as well as extend the shelf life and transport control (Tascioglu et al. 2013; Salem et al. 2016; Xie et al. 2017; Ashmawy et al. 2020), which has been proven to be a new trend for postharvest transportation for the near future. Even using preservative treatments, fruits in a wooden box can still easily undergo fruit decay, have a high total soluble solid content and quality loss due to moisture loss, and be subjected to damage. In addition, the polysaccharides within the fruit can undergo hydrolysis. A preliminary study found that the direct impregnation of essential oils as a preservative constituent into the rubberwood resulted in the rapid release of essential oil vapour into the environment, due 
to the large porous structure of rubberwood. This phenomenon results in undesired fruit odour and flesh damage, as it will accelerate the degradation of the cell wall and pectin.

Activated carbon (AC) is one of the alternative adsorbents used to control the release of volatile compounds from rubberwood. Since AC contains numerous pores and has a suitable physiological structure for aqueous and gas adsorption, it can adsorb essential oils in its structure and control the release of essential oil volatiles into the storage system (Chaemsanit et al. 2017). Chaemsanit et al. (2018) studied the effect of peppermint oil adsorbed via AC on the antifungal activity and quality of dragon fruit. They demonstrated that adsorbed peppermint oil via AC could be released into the packaging system and completely inhibit mould growth during storage. A previous study found that the essential oil absorbed via AC could delay the ripening of fruit during storage and provided less negative effects in terms of fruit quality (Chaemsanit et al. 2018).

In terms of adsorption, the inner cavity of the rubberwood pore allows the essential oil to penetrate the wood cells and encourages the essential oil to be drawn into narrow pores within cell walls via capillary action. Furthermore, AC can absorb the liquid and gaseous molecules of essential oils through van der Waals forces and accumulate them onto the surface of AC. The capillary condensation activates the adsorbed vapour to deposit it into the AC pores, which impedes the release of the active volatiles in essential oils from the rubberwood structure. Consequently, the impregnation of $\mathrm{AC}$ in rubberwood boxes is an alternative approach for improving the controlled release of essential oil volatiles into a system to conduct antimicrobial and antioxidant activities for fruit storage.

Strawberries (Fragaria spp.) are one of the perishable fruits that have short postharvest life. As a part of strawberry deterioration is due to physical damage, strawberries have a high susceptibility to pathogen attacks, especially from Botrytis cinerea (Liu et al. 2018; Ashmawy et al. 2020). The packaging and preservative conditions are vital parameters for post-harvest management during transportation and storage. Chemical fumigation and preservation are used to solve this problem. Unfortunately, the chemicals employed can affect human health. Among the numerous alternatives, essential oils are safe in terms of human health and are eco-friendly. Furthermore, they are recognized as an effective antifungal substance, such that they are widely used in postharvest products to delay microbial growth and maintain overall quality of the strawberries (Tzortzakis 2007; Sangsuwan et al. 2016). A preliminary study found that bergamot oil (BO) is compatible with strawberries because of its similar odorant compounds. In this study, BO in rubberwood boxes impregnated with $\mathrm{AC}$ were used to extend the shelf life of strawberries during transportation. In addition, bergamot fruits are primarily used for essential oil extraction, and $\mathrm{BO}$ contains multiple health functions, e.g., pharmacy usage, as an antiinflammatory, and as an anti-oxidative. The flavour of BO is known to be helpful to increase food flavour.

This research aimed to investigate the controlled release of essential oil absorbed via $\mathrm{AC}$ and impregnated into rubberwood boxes, and its usage in prolonging the shelf life of strawberries during transportation. A rubberwood box impregnated with AC that absorbed BO was developed. The efficiency of the developed rubberwood box in terms of storing strawberries during transportation was examined. In addition, the control release mechanism of the essential oil vapour relating to the degradation delay of strawberries was examined. 


\section{EXPERIMENTAL}

\section{Materials}

Essential oil

Food-grade bergamot oil (BO), derived via steam distillation, was provided by the Thai China Flavours and Fragrances Industry Co., Ltd. (Bangkok, Thailand).

Activated carbon (AC)

The AC powder was provided by the Phytotechnology and Agrochemical Company (Chiang Mai, Thailand).

\section{Rubberwood box}

A rubberwood specimen, $300 \mathrm{~mm}$ (length) by $200 \mathrm{~mm}$ (width) by $100 \mathrm{~mm}$ (thickness), was prepared from a fresh cut sapwood portion of rubberwood lumber acquired from a plantation site in Nakhon Si Thammarat, Thailand. All specimens were conditioned at a temperature of $20{ }^{\circ} \mathrm{C}$ and a relative humidity (RH) of $65 \%$ for two weeks before being used to produce rubberwood boxes.

\section{Fungal strain}

Botrytis cinerea was isolated from infected strawberries and was been cultured on malt extract agar (Merck Ltd., Kenilworth, NJ) at a temperature of $25^{\circ} \mathrm{C} \pm 2{ }^{\circ} \mathrm{C}$ for $7 \mathrm{~d}$. After $7 \mathrm{~d}$. of incubation, plate was observed for colony diameter, spore, color, and the isolates were identified to the species level on the basis of microscopic and morphology characteristics (Pitt and Hocking 2009). The spore suspension was prepared by flooding the slant surface with peptone water and standardised to $10^{6}$ cell $\mathrm{mL}^{-1}$.

\section{Strawberry preparation}

Strawberries (Fragaria x ananassa) (10 g $\pm 3 \mathrm{~g})$ were obtained from a local farm in Chiang Mai, Thailand. They were transported to a laboratory in the Thasala district, Nakhon Si Thammarat Province, Thailand, within $1 \mathrm{~d}$ after harvest. The fruits had a uniform red colour and were free of physical damage and fungal infection. The fruit was washed with normal saline for $1 \mathrm{~min}$, then washed with sterile distilled water, and dried for $30 \mathrm{~min}$ in an air flow cabinet at room temperature (approximately $30^{\circ} \mathrm{C}$ ). All strawberries were kept at $6{ }^{\circ} \mathrm{C}$ before testing (for approximately $4 \mathrm{~h}$ ).

\section{Methods}

Inhibition efficacy of bergamot oil (BO) vapour in a rubberwood box impregnated with activated carbon (AC) against Botrytis cinerea on strawberries

Thirty-five rubberwood boxes in all (28 cm (length) by $18 \mathrm{~cm}$ (width) by $10 \mathrm{~cm}$ (high) were used in the experiments. Five boxes each were prepared according to the following conditions: (a) control condition (AC treatment only), (b) AC plus BO at the 50 $\mu \mathrm{g} \mathrm{g}^{-1}$ level, (c) AC plus BO at the $100 \mu \mathrm{g} \mathrm{g}^{-1}$ level, (d) AC plus BO at the $300 \mu \mathrm{g} \mathrm{g}^{-1}$ level, (e) BO alone at the $50 \mu \mathrm{g} \mathrm{g}^{-1}$ level, (f) BO alone at the $100 \mu \mathrm{g} \mathrm{g}^{-1}$ level, (g) and BO alone at the $300 \mu \mathrm{g} \mathrm{g}^{-1}$ level. The AC powder treatment (which came before BO treatment) was at the $5 \%(\mathrm{w} / \mathrm{v})$ level when it was used. In each case, the mixture was homogenized at 20,000 rpm for $20 \mathrm{~min}$. Then, the wood specimens were soaked in the suspension of BO and $\mathrm{AC}$ under agitation for $1 \mathrm{~h}$, after which the wood specimens were wiped and dried at $60{ }^{\circ} \mathrm{C}$ for $3 \mathrm{~h}$. 
The impregnated rubberwood ( $n=5$ per treatment) was kept in a desiccator to control the moisture until its later usage. Rubberwood without AC absorbing essential oil was used as the control $(n=5)$. The strawberries $(n=30)$ per one box were inoculated with Botrytis cinerea spores and then placed into the rubberwood boxes. All strawberries were stored at $6{ }^{\circ} \mathrm{C}$ for $21 \mathrm{~d}$. Each treatment was done using 5 boxes and 3 replications.

The evaluation of $B$. cinerea growth on the surface of the strawberries was determined from the visible fungal growth. The growth area was rated using a scale of 0 to 5 , where $0=$ no growth; $1=0 \%$ to $20 \%$ growth; $2=20 \%$ to $40 \%$ growth; $3=40 \%$ to $60 \%$ growth; $4=60 \%$ to $80 \%$ growth; and $5=80 \%$ to $100 \%$ growth (Suhem et al. 2017).

The fungal inhibition as a percentage based on the control was calculated by Eq. 1,

The percentage of fungal inhibition $=(\mathrm{A}-\mathrm{B}) / \mathrm{A} \times 100$

where $\mathrm{A}$ is the total score for the control and B is the total score for the treatment.

Shelf life extension of strawberries stored in an essential oil-activated carbon rubberwood box

The strawberries $(n=30)$ were placed into the rubberwood boxes with AC and the rubberwood box with $\mathrm{AC}$ and $\mathrm{BO}$ at a concentration of $100 \mu \mathrm{g} \cdot \mathrm{g}^{-1}$. All strawberries were stored at $6{ }^{\circ} \mathrm{C}$ for $21 \mathrm{~d}$. Fruit quality measurements during the storage of the test strawberries were investigated in the following sections.

\section{Growth rate of the fungal decay}

The growth rate of the fungal decay (natural mould) on the treated strawberries was determined via the appearance and plate counting. Strawberries were kept at $6{ }^{\circ} \mathrm{C}$ for $21 \mathrm{~d}$, and then the total amount of yeast and mould on the strawberries after storage for $3 \mathrm{~d}$ and $21 \mathrm{~d}$ was counted in $\mathrm{CFU} \mathrm{g} \mathrm{g}^{-1}$. The data was expressed as the inhibition percentage of fungal growth, as shown by Eq. 2,

$$
\text { Inhibition (based on control) }=\mathrm{A} / \mathrm{B} \times 100
$$

where $\mathrm{A}$ is the number of the total yeast and mould colonies on the control strawberries minus the number of the total yeast and mould colonies on treatment strawberries (CFU $\mathrm{g}^{-1}$ ) and $\mathrm{B}$ is the number of total yeast and mould colonies on the control strawberries $\left(\mathrm{CFU} \mathrm{g}^{-1}\right)$.

\section{Determination of the total weight loss}

The total weight loss of the strawberries was determined via a digital balance (model STX2202, Ohaus Corp., Parsippany, NJ) and expressed as a percentage of the total strawberry weight loss, according to Eq. 3,

$$
\text { Weight loss }(\%)=\left[\left(W_{1}-W_{2}\right) / W_{1}\right] \times 100
$$

where $W_{1}$ is the strawberry weight $(\mathrm{g})$ at day 0 and $W_{2}$ is the strawberry weight $(\mathrm{g})$ at a specified date.

\section{Determination of colour}

The redness and lightness of the strawberries were measured at three different locations on the fruit and were reported, using the CIE L*a*b* system, as $a^{*}$ and $L^{*}$ values via a colorimeter (Miniscan, Hunter Associates Laboratory, Inc., Reston, VA); $a^{*}$ 
represents the red/green value with green at negative values and red at positive values, whereas $L^{*}$ represents the lightness from black (0) to white (100).

\section{Sensory evaluation}

In order to perform a sensory evaluation of the strawberries in the rubberwood box with $\mathrm{BO}$, the rubberwood box with $\mathrm{AC}+\mathrm{BO}$, and the control rubberwood box after storage for $24 \mathrm{~h}$, a 9-point hedonic scale was used. The following sensory parameters (flavour, colour, taste, texture, and acceptance) were tested and scored by 45 untrained panelists using an acceptance test (Meilgaard et al. 2006). The hedonic scale was used and ranged from 1 for "extremely dislike" to 9 for "extremely like". The strawberries packed in a rubberwood box without essential oil was used as the control treatment.

\section{Microstructure morphology of the rubberwood box with activated carbon (AC)}

The morphological properties of the rubberwood box with $\mathrm{AC}$ and native rubberwood were observed via a scanning electron microscope (SEM). The rubberwood samples were coated with gold before being observed with SEM at $10.0 \mathrm{kV}$ with a $30 \mu \mathrm{m}$ aperture size.

\section{Gas chromatograph-mass spectrometer (GC-MS) analysis}

The effects of the released volatiles from the $\mathrm{BO}$ in the rubberwood box impregnated with AC (which absorbed the $\mathrm{BO}$ ) on the strawberries were examined. The released volatiles from the rubberwood box with $\mathrm{AC}+\mathrm{BO}$ and the surface of the strawberries after storage for $21 \mathrm{~d}$ were extracted via ethyl acetate (Friedman et al. 2000). The chemical components on the surface of the strawberries were extracted via washing with $10 \mathrm{~mL}$ of ethyl acetate for $10 \mathrm{~min}$. The released components from the rubberwood box with $\mathrm{AC}+\mathrm{EO}$ were extracted via washing with $10 \mathrm{~mL}$ of ethyl acetate for $30 \mathrm{~min}$. The extract was flushed with nitrogen gas until the residue extract of each component equalled $1 \mathrm{~mL}$. Then, a $1 \mu \mathrm{L}$ aliquot of each solution was subjected to GC analysis (Agilent Technology, Santa Clara, CA) with a HP-5MS $(30 \mathrm{~m} \times 0.25 \mathrm{~mm}$ and $0.25 \mu \mathrm{m}$ film thickness) capillary column. The initiated oven temperature was programmed at $60{ }^{\circ} \mathrm{C}$ and held for $3 \mathrm{~min}$ and then raised to $100{ }^{\circ} \mathrm{C}$ at a heating rate of $10^{\circ} \mathrm{C} / \mathrm{min}$, then raised to 140 ${ }^{\circ} \mathrm{C}$ at a heating rate of $5^{\circ} \mathrm{C} / \mathrm{min}$, and finally raised to $280{ }^{\circ} \mathrm{C}$ at a heating rate of $20^{\circ} \mathrm{C} \mathrm{min}-1$ and maintained for $15 \mathrm{~min}$. Helium was used as the carrier gas at a flow rate of $1.0 \mathrm{~mL}$ $\min ^{-1}$. The injector was performed in splitless mode, and the injector temperatures and MS transfer line were set at temperatures of $250{ }^{\circ} \mathrm{C}$ and $230{ }^{\circ} \mathrm{C}$, respectively. The volatiles of the $\mathrm{BO}$ were identified via the comparison of their retention time and mass spectra fragmentation with those stored in the NIST $0.8 \mathrm{~L}$ (database/ChemStation data system), which was modified from a study by Ribes et al. (2017).

\section{Statistical analysis}

All results were expressed as the mean \pm standard deviation $(n=3)$. The data were statistically treated using one-way analysis of variance (ANOVA) and Duncan's post hoc test. A $p$-value of less than 0.05 was considered to be statistically significant. The statistical analysis was performed using Statistica software (StatSoft Inc., Tulsa, OK, USA). 


\section{RESULTS AND DISCUSSION}

\section{Inhibition Efficacy of a Rubberwood Box Impregnated with Bergamot Oil (BO) Absorbing Activated Carbon (AC) against Botrytis cinerea on Strawberries}

The Botrytis cinerea growth on strawberries after $3 \mathrm{~d}$ and $21 \mathrm{~d}$ of incubation was evaluated. In the rubberwood boxes impregnated with $\mathrm{AC}, \mathrm{BO}$ at concentrations greater or equal to $100 \mu \mathrm{g} \mathrm{g}^{-1}$ showed a $100 \%$ inhibition of $B$. cinerea after $21 \mathrm{~d}$ of storage, whereas rapid mould growth was found on strawberries (100\%) stored in the control box (with AC) after $3 \mathrm{~d}$ of storage (as shown in Figs. 1 and 2). This result demonstrated that the BO in the rubberwood box impregnated with $\mathrm{AC}$ had lesser amounts of released volatiles in comparison to the boxes without AC (20\% to $40 \%$ inhibition after storage for $21 \mathrm{~d}$ ). However, the volatile components from the $\mathrm{AC}+\mathrm{BO}$ box at day 21 still provided high performance in terms of antimicrobial activities even it was trapped inside the AC. The active components in the rubberwood box with $\mathrm{AC}+\mathrm{BO}$ might provide longer release periods in the box than those in the rubberwood box with only BO. The rubberwood box with AC had an inhibition rate of $3.4 \%$, when compared to the control. This result is due to the moisture absorption capacity of AC; normally, the water molecule has a higher affinity to $\mathrm{AC}$, which could create an environment with less moisture than what is appropriate an important factor for mould growth (Wang et al. 2013).

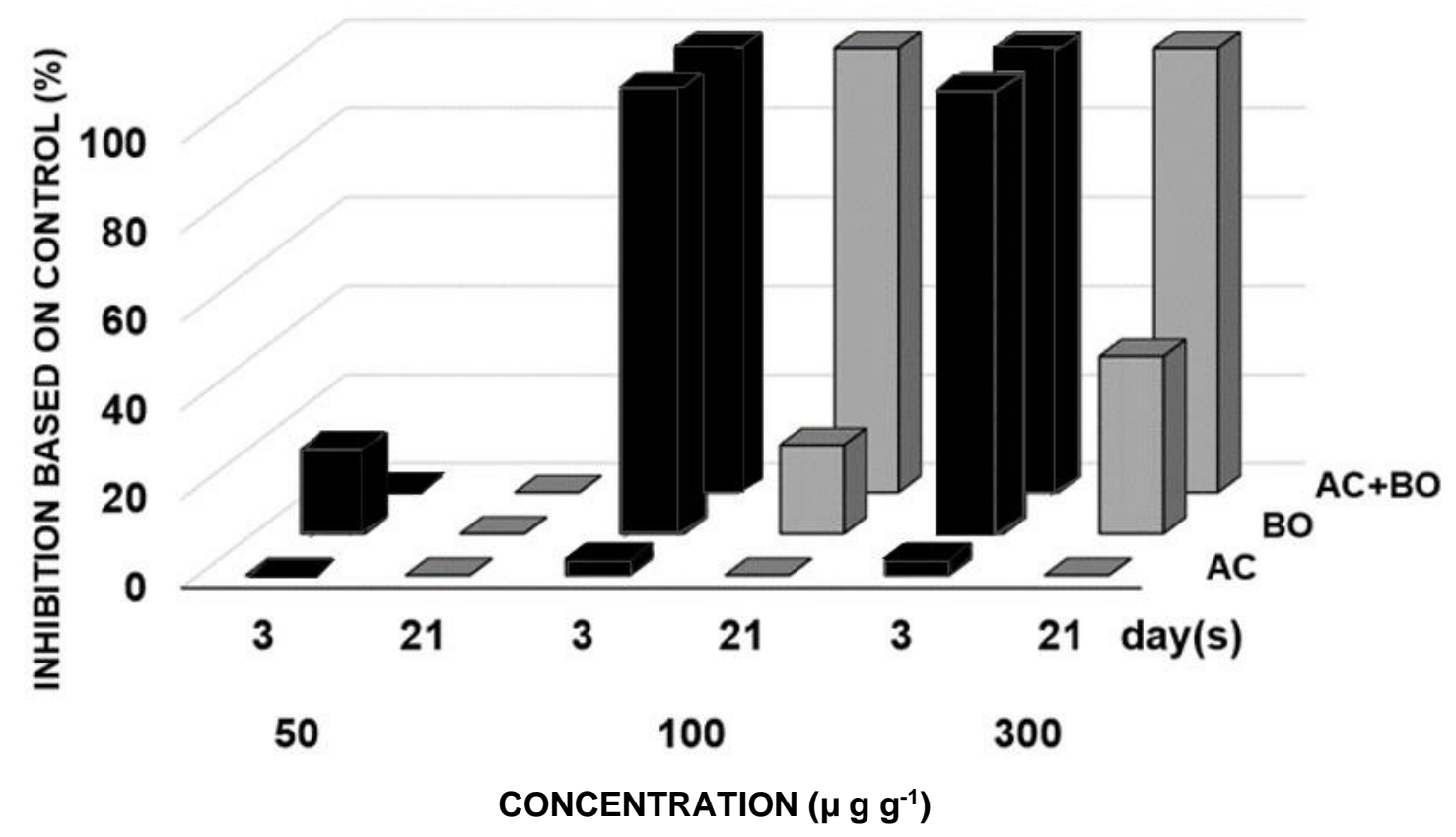

Fig. 1. Inhibition percentage (based on control) of $B O$ in the rubberwood box impregnated with $A C+E O$ against $B$. cinerea on strawberries after $3 d$ and $21 \mathrm{~d}$ of storage

The released volatiles of the BO only rubberwood box and the BO vapour at a concentration of $300 \mathrm{\mu g} \mathrm{g}^{-1}$ had the best inhibition performance at the beginning. However, after $3 \mathrm{~d}$ of storage $(100 \%)$, it damaged the surface of the fruit, which allowed $B$. cinerea to grow on the strawberries and caused strawberry spoilage. The inhibition rate eventually 
decreased to $40 \%$ after storage for $21 \mathrm{~d}$. Tolerant yeast was found in the strawberries that were packed with a high concentration of $\mathrm{BO}\left(300 \mu \mathrm{g} \mathrm{g}^{-1}\right)$ after $25 \mathrm{~d}$ of storage. Conversely, a rubberwood box impregnated with $\mathrm{AC}+\mathrm{BO}$ at a concentration of $100 \mu \mathrm{g} \mathrm{g}^{-1}$ showed the best antifungal properties at longer periods of storage in the present study.

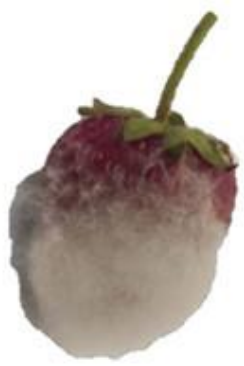

Control

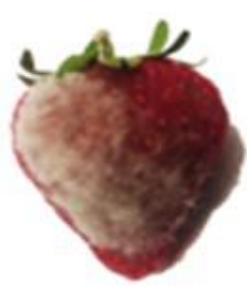

$50 \mu \mathrm{g} \mathrm{g}^{-1}$

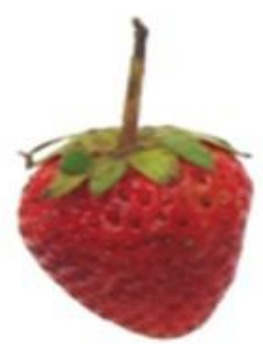

$100 \mu \mathrm{g} \mathrm{g}^{-1}$

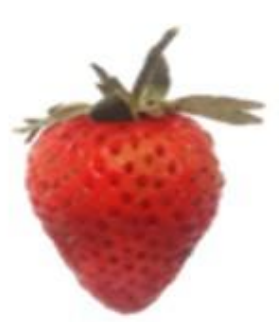

$300 \mu \mathrm{g} \mathrm{g}^{-1}$

Fig. 2. Strawberry appearance after storage in a rubberwood box with $A C+B O$ at concentrations of 0 (control), $50 \mu \mathrm{g} \mathrm{g}^{-1}, 100 \mu \mathrm{g} \mathrm{g}^{-1}$, and $300 \mu \mathrm{g} \mathrm{g}^{-1}$

\section{Extension of Strawberry Shelf Life and Mould Growth Suppression via Storage in a Rubberwood Box Impregnated with AC + BO}

Table 1 shows the qualities of the strawberries stored in rubberwood boxes impregnated with $\mathrm{AC}$ and $\mathrm{AC}+\mathrm{BO}$ at a concentration of $100 \mu \mathrm{g} \mathrm{g}^{-1}$. The rubberwood box that included BO had a $100 \%$ inhibition of yeast and mould growth after $21 \mathrm{~d}$ of storage. In addition, $B$. cinerea could not be found on the surface of the strawberries. Conversely, yeast infections and $B$. cinerea growth were found on the control treatment (impregnated with $\mathrm{AC}$ ) within $3 \mathrm{~d}$ of storage.

Table 1. Strawberry Quality After Storage in Rubberwood Box for $21 \mathrm{~d}$ at $6{ }^{\circ} \mathrm{C}$

\begin{tabular}{|c|c|c|c|c|c|c|}
\hline \multirow{3}{*}{$\begin{array}{l}\text { Storage } \\
\text { Time } \\
\text { (d) }\end{array}$} & \multicolumn{6}{|c|}{ Qualities } \\
\hline & \multicolumn{2}{|c|}{ Mold growth } & \multicolumn{2}{|c|}{ Weight Loss } & \multicolumn{2}{|c|}{ Color (Redness) } \\
\hline & $\begin{array}{c}\text { Box with } \\
\text { AC }\end{array}$ & $\begin{array}{l}\text { Box with } \\
A C+B O\end{array}$ & Box with AC & $\begin{array}{l}\text { Box with } \\
A C+B O\end{array}$ & Box with $A C$ & $\begin{array}{l}\text { Box with } \\
A C+B O\end{array}$ \\
\hline 3 & $\begin{array}{l}2.5 \pm \\
0.3^{\mathrm{aB}}\end{array}$ & $\begin{array}{l}100 \pm \\
0.00^{\mathrm{aA}}\end{array}$ & $\begin{array}{l}0.73 \pm \\
0.14^{\mathrm{bA}}\end{array}$ & $\begin{array}{l}0.70 \pm \\
0.32^{\mathrm{bA}}\end{array}$ & $\begin{array}{c}29.63 \pm \\
4.34^{\mathrm{dA}}\end{array}$ & $\begin{array}{c}26.00 \pm \\
3.76^{\mathrm{cB}}\end{array}$ \\
\hline 7 & $\begin{array}{l}0.0 \pm \\
0.0^{\mathrm{bB}}\end{array}$ & $\begin{array}{l}100 \pm \\
0.00^{\mathrm{aA}}\end{array}$ & $\begin{array}{l}0.56 \pm \\
0.18^{\mathrm{bB}}\end{array}$ & $\begin{array}{l}0.72 \pm \\
0.06^{\mathrm{bA}}\end{array}$ & $\begin{array}{c}32.06 \pm \\
1.17^{\mathrm{CA}}\end{array}$ & $\begin{array}{c}26.51 \pm \\
3.34^{\mathrm{CB}}\end{array}$ \\
\hline 14 & $\begin{array}{l}0.0 \pm \\
0.0^{\mathrm{bB}}\end{array}$ & $\begin{array}{l}100 \pm \\
0.00^{\mathrm{aA}}\end{array}$ & $\begin{array}{l}1.59 \pm \\
0.13^{\mathrm{aA}}\end{array}$ & $\begin{array}{l}1.12 \pm \\
0.26^{\mathrm{aB}}\end{array}$ & $\begin{array}{c}35.976 \pm \\
5.44^{\mathrm{bA}}\end{array}$ & $\begin{array}{c}31.00 \pm \\
0.56^{\mathrm{bB}}\end{array}$ \\
\hline 21 & $\begin{array}{l}0.0 \pm \\
0.0^{\mathrm{bB}}\end{array}$ & $\begin{array}{l}100 \pm \\
0.00^{\mathrm{aA}}\end{array}$ & $\begin{array}{l}1.59 \pm \\
0.45^{\mathrm{aA}}\end{array}$ & $\begin{array}{l}1.12 \pm \\
1.14^{\mathrm{aB}}\end{array}$ & $\begin{array}{c}39.01 \pm \\
1.50^{\mathrm{aA}}\end{array}$ & $\begin{array}{c}35.65 \pm \\
1.94^{\mathrm{aB}}\end{array}$ \\
\hline $\begin{array}{l}(p \text {-valu } \\
\text { signific }\end{array}$ & fferen & alue $<$ & $\begin{array}{l}\mathrm{nn} \text { with } \\
\mathrm{n} \text { the sal }\end{array}$ & supers & $\begin{array}{l}\text { are signifi } \\
\text { uperscrip }\end{array}$ & \\
\hline
\end{tabular}

\section{Weight Loss}

Table 1 presents the total weight loss of the strawberries, which gradually decreased during storage at $6{ }^{\circ} \mathrm{C}$. The total weight loss of the strawberries in the rubberwood box impregnated with $\mathrm{AC}$ reached $1.6 \%$ after storage at $6{ }^{\circ} \mathrm{C}$ for $21 \mathrm{~d}$. Strawberries in a rubberwood box impregnated with $\mathrm{AC}+\mathrm{BO}$ showed significantly less weight loss than those 
stored in a rubberwood box impregnated with AC only. This is probably caused by the hydrophobic vapour that could seal the open pores of fruit, therefore preventing water loss (Guerra et al. 2016). The different results of the present study could be due to the low amount of released $\mathrm{BO}$ vapours from the adsorbed material while in low temperature $\left(6^{\circ} \mathrm{C}\right)$ storage. This phenomenon is due to the increasing water content that occurs when the strawberries are damaged.

\section{Colour}

The redness $\left(a^{*}\right)$ of the strawberries in the rubberwood boxes imprinted with $\mathrm{AC}$ and with $\mathrm{AC}+\mathrm{BO}$ increased during storage. This result confirms that the application of $\mathrm{AC}$ in a rubberwood box that contained $\mathrm{BO}$ provided an increase in overall redness appeal of the strawberry fruit in the same way as in the control box. This demonstrated that AC was effective for the release of $\mathrm{BO}$ vapours at a controlled rate. As a result, the quality of strawberries was preserved for $21 \mathrm{~d}$ at a temperature of $6{ }^{\circ} \mathrm{C}$.

\section{Sensory Evaluation of the Strawberries Treated with Essential Oil}

Table 2 shows the results of the sensory evaluation of the strawberries stored in the three developed rubberwood boxes $(\mathrm{AC}, \mathrm{BO}$, and $\mathrm{AC}+\mathrm{BO})$. The released bergamot vapours from the rubberwood box impregnated with $\mathrm{AC}+\mathrm{BO}$ at a concentration of 100 $\mu \mathrm{g} \mathrm{g}^{-1}$ did not significantly affect the strawberry colour, taste, and texture, i.e., ranked as a moderate like. This result was consistent with the finding of Sangsuwan et al. (2016). The flavour acceptant scores of the strawberries stored with BO alone were less than those of the strawberries stored in the control rubberwood box (without BO). However, using the rubberwood box that contained $\mathrm{BO}$ without $\mathrm{AC}$ provided an unacceptable score (less than 5 ) in terms of flavour, odour, and firmness in strawberries. The undesirable characteristics of these strawberries were probably due to the higher amount of trapped volatile essential oils in the strawberries. The combination of AC and BO in the packaging could delay the amount of released bergamot volatiles, which affects the acceptability, quality, and deterioration rate of the strawberries. However, the strawberries in the rubberwood box with $\mathrm{AC}+\mathrm{BO}$ still had less acceptability, in terms of flavour, compared with the strawberries subjected to a non-essential oil application as performed by Perdones et al. (2012).

Table 2. Acceptance of the Strawberry in Different Rubberwood Packaging using 9-Point Hedonic Scale

\begin{tabular}{|c|c|c|c|}
\hline Attribute & Rubberwood with AC & Rubberwood with BO & Rubberwood with AC + BO \\
\hline Color & $8 \pm 0.5^{\mathrm{a}}$ & $6 \pm 0.2^{\mathrm{b}}$ & $7 \pm 0.8^{\mathrm{a}}$ \\
\hline Flavor & $7 \pm 0.6^{\mathrm{a}}$ & $4 \pm 0.4^{\mathrm{b}}$ & $6 \pm 0.5^{\mathrm{a}}$ \\
\hline Taste & $6 \pm 0.7^{\mathrm{a}}$ & $4 \pm 0.3^{\mathrm{c}}$ & $5 \pm 0.4^{\mathrm{b}}$ \\
\hline Texture & $7 \pm 0.5^{\mathrm{a}}$ & $4 \pm 0.5^{\mathrm{b}}$ & $6 \pm 0.5^{\mathrm{a}}$ \\
\hline
\end{tabular}

Note: Values in the same row with different superscripts are significantly different $(P<0.05)$ 9-Point Hedonic Scale: 1=Like Extremely; 2=Like Very Much; 3=Like Moderately; 4=Like Slightly; 5=Neither Like nor Dislike; 6=Dislike Slightly; 7=Dislike Moderately; 8=Dislike Very Much; 9=Dislike Extremely 


\section{Microstructure Morphology}

Figure 3 illustrates the microstructure of the rubberwood boxes with and without AC. Native rubberwood has a high surface area and large pore structure, which was found to confer high radon absorption (Lee et al. 2017) and desorption performance of preservatives. Conversely, the rubberwood boxes impregnated with AC presented the coating of AC on the rubberwood surface. Since the size of AC powder is approximately $100 \mu \mathrm{m}$, the AC suspension could diffuse into the open end of the rubberwood cells (located at an approximate depth of $121 \mathrm{~nm}$ from the surface) and become trapped on the outer surface of the rubberwood, after which the essential oil could be absorbed via hollow capillaries of the AC and easily penetrate the rubberwood. The essential oil should then migrate into the small diameter openings via diffusion (Tarmian et al. 2020). The essential oil passed through the pits in the cell walls into the adjoining tracheids. The absorbed essential oil was transported in a radial direction until reaching a high enough volume (three-fourths of its cell cavities), thus reaching equilibrium absorption. The horizontal surface did not show a different thicknesses due to the suspended AC compared to the thickness of the control. Some AC colloidal particles were concentrated near the center of the pore (Malkov et al. 2001) and fixed to the rubberwood surface.

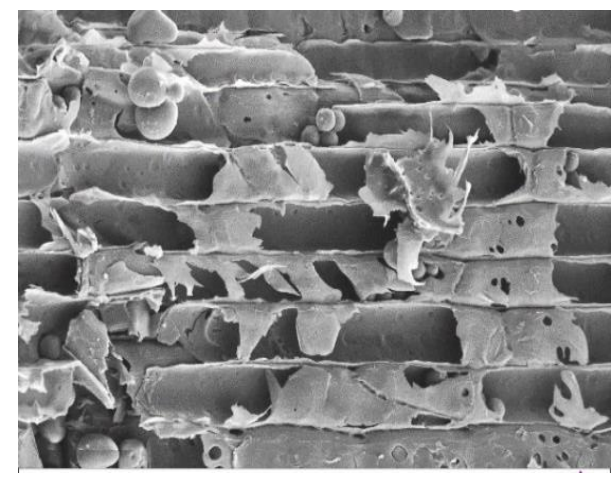

(a)

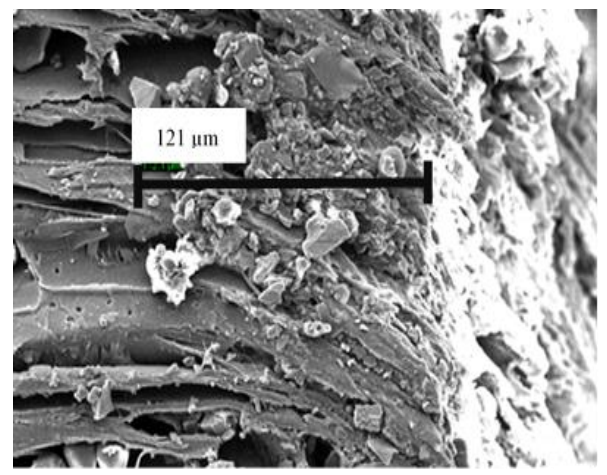

(b)

Fig. 3. Diagram of the microstructure morphology of native rubberwood (a); and the rubberwood box impregnated with $A C(b)$

\section{Gas Chromatography Mass Spectroscopy (GC-MS) Results}

Table 3 shows the detected amounts of the $\mathrm{BO}$ volatile components in a rubberwood boxes impregnated with $\mathrm{AC}+\mathrm{BO}$, as well as the volatile components on the surface of the strawberries after treating with $\mathrm{BO}$ vapours. It was revealed that the most abundant constituents of $\mathrm{BO}$ in a rubberwood box impregnated with $\mathrm{AC}+\mathrm{EO}$ were as follows: $\mathrm{D}$ limonene $(25.49 \%$ ) (a monoterpene hydrocarbon), linalyl acetate $(24.44 \%)$ (a monoterpene ester), and linalool (19.77\%) (a monoterpene alcohol). These results were in agreement with the trends shown in the experiment performed by Eleni et al. (2009), who found that BO was comprised of D-limonene (25.62\% to $53.19 \%$ ), linalyl acetate $(15.61 \%$ to $40.37 \%$ ), and linalool (1.75\% to 20.26\%). It was also in agreement with Marei et al. (2012), who report that $\mathrm{BO}$ was a potent antifungal compound. The primary active components in BO were limonene, which accounted for $59.2 \%$ (Nabiha et al. 2010), followed by linalyl acetate and linalool. After storage for $21 \mathrm{~d}$, the total remaining amount of the components in the rubberwood box impregnated with $\mathrm{AC}+\mathrm{BO}$ decreased, as they became released and dispersed onto the surfaces of the strawberries. The major volatile constituents on the surface of the strawberries were the active components of BO and their derivatives, due to 
their volatility and degradation throughout storage (Table 3). This phenomenon is related to the antifungal activity of $\mathrm{BO}$ on the strawberries during storage.

Table 3. Components of the Bergamot Oil from the Rubberwood Box Impregnated with AC + BO and the Surface of the Strawberries After Storage

\begin{tabular}{|c|c|c|c|c|}
\hline & & & \multicolumn{2}{|c|}{ Component Area (\%) } \\
\cline { 4 - 5 } Constituents & R.T. & R.I. & $\begin{array}{c}\text { Bergamot oil in } \\
\text { rubberwood box with AC }\end{array}$ & $\begin{array}{c}\text { Bergamot oil } \\
\text { on } \\
\text { Strawberry } \\
\text { surface after } \\
21 \text { d }\end{array}$ \\
\hline $2(10)$-Pinene & 7.6674 & 934 & 1.43 & 0.95 \\
\hline$(-)-\beta-P i n e n e$ & 7.7572 & 973 & 10.52 & - \\
\hline D-Limonene & 8.7731 & 1023 & 25.49 & 2.60 \\
\hline Gamma-Terpinene & 9.3674 & 1060 & 9.93 & 0.82 \\
\hline Linalool & 10.2179 & 1094 & 19.77 & 14.17 \\
\hline Linalyl acetate & 13.7692 & 1240 & 24.44 & 13.01 \\
\hline Caryophyllene & 17.063 & 1419 & 0.93 & - \\
\hline
\end{tabular}

\section{Possible Mode of Action}

Rubberwood boxes impregnated with AC are shown in Figs. 3 and 4. The penetration depth of the AC impregnated into the surface of the rubberwood box was 121 $\mu \mathrm{m}$. The BO components were adsorbed by the $\mathrm{AC}$ and the wood structure by physical attraction via hydrogen bonding and van der Waals forces. The BO vapours were stored in cellulose structures of the rubber wood and diffused into the AC structures over time. The diffusion process causing the adsorption of $\mathrm{BO}$ into the $\mathrm{AC}$ was dependent on the three following main factors: (a) the adsorbent characteristics including the adsorbent nature, e.g., functional group, the surface area, the distribution of pore size, and the ash content; (b) the adsorbate characteristics, including the adsorbate nature, e.g., functional group, the molecular weight, polarity, hydrophobicity, size, solubility, and pKa; and (c) the solution characteristics, including the $\mathrm{pH}$, the concentration of the adsorbate, and the temperature (Radovic et al. 1997; Villacañas et al. 2006). Conversely, the electrostatic and dispersive interactions between the adsorbate and adsorbent are involved in this process. Franz et al. (2000) demonstrated that the liquid aromatic compounds, mostly absorbed on basal planes, corresponded to approximately $90 \%$ of the carbon surface. The detected molecules in both the rubberwood box impregnated with $\mathrm{AC}+\mathrm{BO}$ and the surfaces of the strawberries were mostly of the terpenoid group (a high proportion of monoterpenes) and had a low molecular weight (136.2 to $212.3 \mathrm{~g} \mathrm{~mol}^{-1}$ ). All these BO constituents could be adsorbed into the micropores of the $\mathrm{AC}$ and released to the environment (as shown in Fig. 4.). The schematic diagram of the $\mathrm{BO}$ and $\mathrm{BO}$ vapours on the surface of the strawberry fruits after storage for $21 \mathrm{~d}$ illustrated that the volatile components of BO present on the surface of the strawberries were transformed. This phenomenon was affected by dehydration, oxidation, rearrangement, and degradation processes during storage. However, not all the released components of BO vapour were present on the surface of the strawberries. Some components might be emitted and floated into the air surrounding the strawberries, so the released molecules could not be found on the strawberries. Furthermore, the components containing a hydroxyl group or cyclic hydrocarbon would be still strongly attached to the $\mathrm{AC}$ and therefore could not be released into the air at a temperature of $25^{\circ} \mathrm{C}$. 
The primary antifungal substances of BO could be changed into many structural forms, e.g., myrene, pinene, cymene carvone, linalool dioxide, and 9-hydroxy-linalool (Sell 2009). These compounds were found on the surface of the strawberries after being storaged in a rubberwood box impregnated with BO. This study found that D-limonene is a monoterpene hydrocarbon, which is recognized as an antifungal agent (Fisher and Phillips 2008) and a potent substance that could convert into linalool and $\alpha$-terpineol via a limonene hydroxylase enzyme (Marmulla and Harder 2014) as well as carveol (Glonek et al. 2017), carvone, and limonene oxide via an oxidization process in moist air conditions. The component area of limonene was reduced after storage, whereas the linalool content increased, since it was obtained via a molecule transformation process, rearrangement process of limonene derivatives and strawberry volatile component (Du et al. 2011).

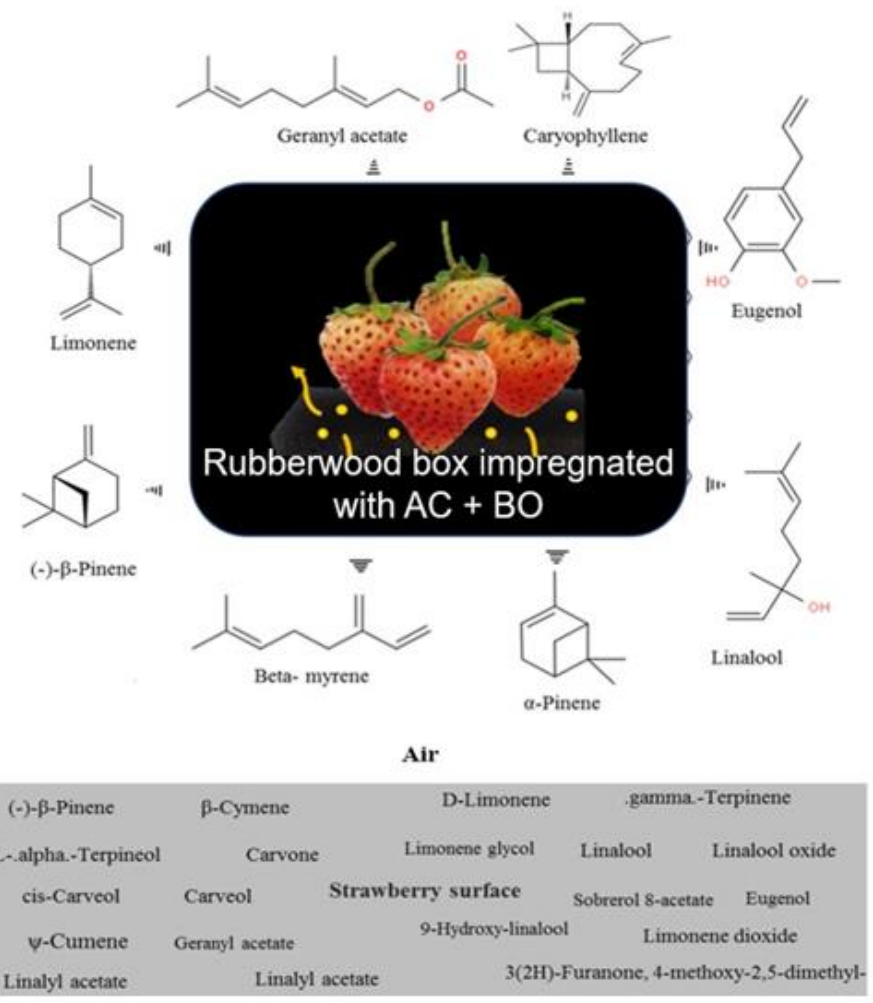

Fig. 4. The releasing mechanism of the $\mathrm{BO}$ components from the rubberwood box impregnated with $A C+B O$ into the air and the adsorption of the released components into the strawberry fruits

Consequently, the results conformed those of other reports, indicating that the antifungal ability of BO vapour was dependent on the suitable ratio of its primary components, e.g., limonene, linalyl acetate, and linalool. The reduction of these three primary components caused reduced antifungal properties on the strawberries, therefore grey mould could grow on the strawberries after $14 \mathrm{~d}$ of storage.

\section{CONCLUSIONS}

1. Activated carbon is an effective release controller of bergamot volatiles from the rubberwood box impregnated with activated carbon (AC) and bergamot oil (BO). 
2. A rubberwood box impregnated with $\mathrm{AC}+\mathrm{BO}$ at a concentration of $100 \mu \mathrm{g} \mathrm{g}^{-1}$ can delay the growth of $B$. cinerea on strawberries during storage at a temperature of $6{ }^{\circ} \mathrm{C}$ for a least $21 \mathrm{~d}$ and impede the loss of quality in strawberries with a good organoleptic property.

3. The combination of $\mathrm{AC}$ and rubberwood influenced a reduction in the degradation rate of strawberries, due to prolonging their shelf life. This technique is suitable for manufacturing active wood packaging for fruit storage in the future.

\section{ACKNOWLEDGMENTS}

This work was supported by the Thailand Research Fund (TRF) through the research and researcher for industries (RRI) [Grant No. PHD61I0005]; Timber Engineering of Krabi CO., LTD; and Walailak University, Thailand.

\section{REFERENCES CITED}

Ashmawy, N. A., Salem, M. Z. M., El Shanhorey, N., Al-Huqail, A. A., Ali, H. M., and Behiry, S. I. (2020). "Eco-friendly wood-biofungicidal and antibacterial activities of various Coccoloba uvifera L. leaf extracts: HPLC analysis of phenolic and flavonoid compounds," BioResources 15(2), 4165-4187. DOI: 10.15376/biores.15.2.4165-4187

Chaemsanit, S., Matan, N., and Matan, N. (2017). "Activated carbon for food packaging application," Walailak Journal of Science \& Technology 15(4), 255-271.

Chaemsanit, S., Matan, N., and Matan, N. (2018). "Effect of peppermint oil on the shelflife of dragon fruit during storage," Food Control 90, 172-179. DOI: 10.1016/j.foodcont.2018.03.001

Du, X., Plotto, A., Baldwin, E., and Rouseff, R. (2011). "Evaluation of volatiles from two subtropical strawberry cultivars using GC-olfactometry, GC-MS odor activity values, and sensory analysis," Journal of Agricultural and Food Chemistry 59(23), 1256912577. DOI: $10.1021 /$ jf2030924

Fisher, K., and Phillips, C. (2008). "Potential antimicrobial uses of essential oils in food: Is citrus the answer?," Trends in Food Science \& Technology 19(3), 156-164. DOI: 10.1016/j.tifs.2007.11.006

Franz, M., Arafat, H. A., and Pinto, N. G. (2000). "Effect of chemical surface heterogeneity on the adsorption mechanism of dissolved aromatics on activated carbon," Carbon 38(13), 1807-1819. DOI: 10.1016/S0008-6223(00)00012-9

Friedman, M., Kozukue, N., and Harden, L. A. (2000). "Cinnamaldehyde content in foods determined by gas chromatography-mass spectrometry," Journal of Agricultural and Food Chemistry 48(11), 5702-5709. DOI: 10.1021/jf000585g

Glonek, K., Wróblewska, A., Makuch, E., Ulejczyk, B., Krawczyk, K., Wróbel, R. J., Koren, Z. C., and Michalkiewicz, B. (2017). "Oxidation of limonene using activated carbon modified in dielectric barrier discharge plasma," Applied Surface Science 420, 873-881. DOI: 10.1016/j.apsusc.2017.05.136

Guerra, I. C. D., de Oliveira, P. D. L., Santos, M. M. F., Lúcio, A. S. S. C., Tavares, J. F., Barbosa-Filho, J. M., Madruga, M. S., and de Souza, E. L. (2016). "The effects of composite coatings containing chitosan and Mentha (piperita L. or $x$ villosa Huds) 
essential oil on postharvest mold occurrence and quality of table grape cv. Isabella," Innovative Food Science \& Emerging Technology 34, 112-121. DOI: 10.1016/j.ifset.2016.01.008

Lee, M., Jang, J., Lee, S., and Park, S. (2017). "Comparison of the radon absorption capacity of carbonized boards from different wood-based panels," BioResources 12(3), 6427-6433. DOI: 10.15376/biores.12.3.6427-6433

Liu, C., Zheng, H., Sheng, K., Liu, W., and Zheng, L. (2018). "Effects of melatonin treatment on the postharvest quality of strawberry fruit," Postharvest Biology and Technology 139, 47-55. DOI: 10.1016/j.postharvbio.2018.01.016

Malkov, S., Tikka, P., and Gullichsen, J. (2001). "Towards complete impregnation of wood chips with aqueous solutions. Part 2. Studies on water penetration into softwood chips," Paperi ja Puu-Paper and Timber 83(8), 1-6.

Marei, G. I. K., Rasoul, M. A. A., and Abdelgaleil, S. A. M. (2012). "Comparative antifungal activities and biochemical effects of monoterpenes on plant pathogenic fungi," Pesticide Biochemistry and Physiology 103(1), 56-61. DOI:

10.1016/j.pestbp.2012.03.004

Marmulla, R., and Harder, J. (2014). "Microbial monoterpene transformations - A review," Frontiers in Microbiology 5, 1-14. DOI: 10.3389/fmicb.2014.00346

Meilgaard, M. C., Carr, B. T., and Civille, G. V. (2006). "Pairwise ranking test: Friedman analysis-Comparing several samples in all possible pairs," in: Sensory Evaluation Techniques, CRC Press, Boca Raton, FL, pp. 109-111.

Nabiha, B., Abdelfatteh, E. O., Faten, K., Hervé, C., and Moncef, C. M. (2010). "Chemical composition of bergamot (Citrus bergamia Risso) essential oil obtained by hydrodistillation," Journal of Chemistry and Chemical Engineering 4(4), 60-62.

Perdones, A., Sánchez-González, L., Chiralt, A., and Vargas, M. (2012). "Effect of chitosan-lemon essential oil coatings on storage-keeping quality of strawberry," Postharvest Biology and Technology 70, 32-41. DOI:

10.1016/j.postharvbio.2012.04.002

Pitt, J. I., and Hocking, A. D. (2009). Fungi and Food Spoilage, Vol. 519, Springer, New York.

Radovic, L. R., Silva, I. F., Ume, J. I., Menéndez, J. A., Leon, C. A. L. Y., and Scaroni, A. W. (1997). "An experimental and theoretical study of the adsorption of aromatics possessing electron-withdrawing and electron-donating functional groups by chemically modified activated carbons," Carbon 35(9), 1339-1348. DOI: 10.1016/S0008-6223(97)00072-9

Ribes, S., Fuentes, A., Talens, P., Barat, J. M., Ferrari, G., and Donsì, F. (2017). "Influence of emulsifier type on the antifungal activity of cinnamon leaf, lemon and bergamot oil nanoemulsions against Aspergillus niger," Food Control 73(Part B), 784-795. DOI: 10.1016/j.foodcont.2016.09.044

Salem, M. Z. M., Zidan, Y. E., Mansour, M. M. A., El Hadidi, N. M. N., and Elgat, W. A. A. A. (2016). "Antifungal activities of two essential oils used in the treatment of three commercial woods deteriorated by five common mold fungi," International Biodeterioration \& Biodegradation 106, 88-96. DOI: 10.1016/j.ibiod.2015.10.010

Sangsuwan, J., Pongsapakworawat, T., Bangmo, P., and Sutthasupa, S. (2016). "Effect of chitosan beads incorporated with lavender or red thyme essential oils in inhibiting Botrytis cinerea and their application in strawberry packaging system," LWT - Food Science and Technology 74, 14-20. DOI: 10.1016/j.lwt.2016.07.021 
Sell, C. (2009). "Chemistry of essential oils," in: Handbook of Essential Oils, K. H. C. Başer, and G. Buchbauer (ed.), CRC Press, New York, NY, pp. 128-157.

Suhem, K., Matan, N., Matan, N., Danworaphong, S., and Aewsiri, T. (2017). "Enhanced antifungal activity of michelia oil on the surface of bamboo paper packaging boxes using helium-neon (HeNe) laser and its application to brown rice snack bar," Food Control 73(Part B), 939-945. DOI: 10.1016/j.foodcont.2016.10.006

Tarmian, A., Zahedi Tajrishi, I., Oladi, R., and Efhamisisi, D. (2020). "Treatability of wood for pressure treatment processes: A literature review," European Journal of Wood and Wood Products 78, 635-660. DOI: 10.1007/s00107-020-01541-w

Tascioglu, C., Yalcin, M., Sen, S., and Akcay, C. (2013). “Antifungal properties of some plant extracts used as wood preservatives," International Biodeterioration \& Biodegradation 85, 23-28. DOI: 10.1016/j.ibiod.2013.06.004

Tzortzakis, N. G. (2007). "Maintaining postharvest quality of fresh produce with volatile compounds," Innovative Food Science \& Emerging Technology 8(1), 111-116. DOI: 10.1016/j.ifset.2006.08.001

Villacañas, F., Pereira, M. F. R., Órfão, J. J. M., and Figueiredo, J. L. (2006). "Adsorption of simple aromatic compounds on activated carbons," Journal of Colloid and Interface Science 293(1), 128-136. DOI: 10.1016/j.jcis.2005.06.032

Wang, R., Amano, Y., and Machida, M. (2013). "Surface properties and water vapor adsorption-desorption characteristics of bamboo-based activated carbon," Journal of Analytical and Applied Pyrolysis 104, 667-674. DOI: 10.1016/j.jaap.2013.04.013.

Xie, Y., Wang, Z., Huang, Q., and Zhang, D. (2017). "Antifungal activity of several essential oils and major components against wood-rot fungi," Industrial Crops and Products 108, 278-285. DOI: 10.1016/j.indcrop.2017.06.041

Article submitted: October 29, 2020; Peer review completed: December 12, 2020; Revised version received and accepted: January 10, 2021; Published: January 21, 2021. DOI: 10.15376/biores.16.1.1726-1739 